\title{
Apoptosis Activity of Ruellia tuberosa Leaf Extract on HUH-7, SW480 \& HEK293T Cells
}

Piyali Das, Vishal Sharma, Nilanjana Deb, Shila Elizabeth Besra*

Central Instrumentation Facility and Cancer Biology \& Inflammatory Disorder Division, CSIR- Indian Institute of Chemical Biology, 4 , Raja S.C. Mullick Road, Kolkata-700032, West Bengal, India.

*Corresponding author's E-mail: shilabesra@iicb.res.in

Received: 14-10-2021; Revised: 22-12-2021; Accepted: 30-12-2021; Published on: 15-01-2022. ABSTRACT

The plant Ruellia tuberosa is a traditional medicine as a broad-spectrum medicine. Ruellia tuberosa leaf extract (RTLE) showed potential anti-cancer activity in our previous study on HepG2 cells. RTLE significantly inhibited the cell viability in a time and concentration dependent manner on the Huh-7 and SW480 cell lines and being a normal human cell line there was insignificant inhibition in Hek293T cell line. Cell images clearly showed nuclear disintegration, several signs of apoptosis like chromatin condensation, nuclear fragmentation and formation of apoptotic bodies whereas the untreated control cells were with intact nuclei when treated with RTLE on (Huh-7) hepatocellular carcinoma cells. Flow cytometric analysis confirmed the presence of apoptotic cells in the early and late apoptotic stages of Huh-7 and SW480 cells but not in Hek293T. Cell cycle phase arrest was observed in the G0/G1 phase in Huh-7 and SW480 cells but not in Hek293T cells. MMP shift assay exhibited significant change in the RTLE treated Huh-7 and SW480cells but no such shift was observed in Hek293T cells. These findings suggest that RTLE mediates cytotoxicity in hepatocellular and colon carcinoma cells via apoptosis without exerting any such toxic effect on normal human embryonic kidney cells. Further mechanistic studies are going on to determine the different pathways contributing to apoptosis.

Keywords: Ruellia tuberosa leaf, Hepatocellular carcinoma, Colorectal carcinoma, Apoptosis.

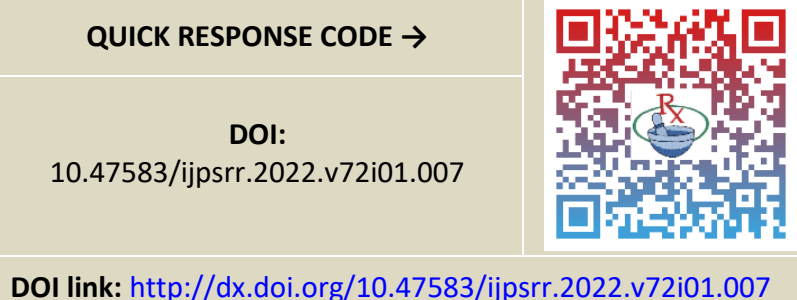

\section{INTRODUCTION}

$\mathrm{C}$ ancer is a group of diseases involving abnormal cell growth with the potential to invade or spread to other parts of the body. Mutations in genes can also cause cancer by accelerating cell division rates or inhibiting normal controls on the system, such as cell cycle arrest or programmed cell death. ${ }^{1}$ Liver and Colon are the major organs of human body. The liver is the largest gland in the body and performs an astonishingly large number of tasks that impact all body systems. Hepatocellular carcinoma (HCC), or hepatoma accounts for more than $90 \%$ of all cases of primary liver cancer. ${ }^{2}$ It is the sixth most common type of cancer worldwide and has shown a significant increase in its incidence, becoming third leading cause of cancer-related mortality. ${ }^{3}$ Colorectal cancers is one of the most common cancer in people over 50 years both in the developed and less developed world. The types of cells that most commonly give rise to colorectal cancers is the adenocarcinoma which arise from inner line of the inside tissue of colon and rectum. Treatment efficiency of colorectal and liver cancer are very low, therefore colorectal and liver cancer prevention and control is extremely important. Drug discovery from medicinal plants has played a very important role in the treatment of cancer. Ruellia tuberosa was used as a cooling agent in urinary problem and also used for treatment of uterine fibroids. It has been recently incorporated as a component in an herbal drink in Taiwan. In Siddha system of medicine, leaves are given with liquid copal as remedy for gonorrhea and ear diseases. ${ }^{4}$ The Ruellia tuberosa leaf extract and its constituents have been reported to possess anti-cancer activity against EAC cells. ${ }^{5}$ In our previous work we have studied on hepatocellular carcinoma (HepG2) cell line. HepG2 is a hepatocellular carcinoma originated from 15year-old American male Caucasian. ${ }^{6}$ But, no such work has been reported on another very well-known hepatocellular carcinoma cell line i.e. Huh-7, a 57-year-old Japanese origin hepatocellular carcinoma cell line. Therefore, we evaluated the anti-proliferative activity of Ruellia tuberosa leaf extract (RTLE) using Huh-7hepatocellular carcinoma cell line. Due to high mortality rate of colorectal carcinoma we have studied the effect of RTLE on SW480 cell line, a colorectal cancer line which is a 50 year male Caucasian. The toxic effect of Ruellia tuberosa leaf extract on HEK293T cell line was also investigated.

\section{MATERIALS AND METHODS}

\section{Chemicals}

DMEM (Gibco), fetal bovine serum(FBS), Trypsin (Gibco, USA), Penicillin-streptomycin (Biowest, Germany), Gentamycin (Nicholas, India), HEPES, L-glutamine, MTT [3(4,5-dimethylthiazol-2-yl)-2,5-diphenyltetrazolium bromide)], DMSO (dimethylsulphoxide), Acridine orange, Ethidium bromide, ethylene diamine tetra acetic acid

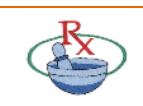


(EDTA) Agarose (Puregene), Proteinase k (SRL), RNAse, JC1 dye, Propidium iodide (Sigma), Chloroform, isoamyl alcohol, Methanol (Merk), and all other chemicals and reagents were of analytical grade and procured locally.

\section{Cell culture}

Huh-7 was obtained from Nation Centre for Cell Science, Pune, India. The cells were cultured and routinely maintained in DMEM medium and the medium was supplemented with $10 \%$ heat inactivated fetal bovine serum (FBS), penicillin (100 units/ml), streptomycin $(100 \mu \mathrm{g} / \mathrm{ml})$, gentamycin $(100 \mu \mathrm{g} / \mathrm{ml})$ and were incubated at $37{ }^{\circ} \mathrm{C}$ in a humidified atmosphere containing $5 \% \mathrm{CO}_{2}$ inside a $\mathrm{CO}_{2}$ incubator. All cell lines were adherent in nature.

\section{Collection, Identification, Extraction and preparation of} test samples

The leaves of Ruellia tuberosa were collected from the nursery of Ramakrishna Mission Ashram, Narendrapur. The plant was identified by Dr. K. Karthigeyan, scientist C, Central National Herbarium, Indian Botanical Garden, Howrah, India. Leaves of Ruellia tuberosa were collected, shade dried and grinded into fine dust.200gm of Ruellia tuberosa leaf powder was taken in a conical flask and soaked in $500 \mathrm{ml}$ hexane for 3 days with occasionally shaking for removal of fat. After 3 days, the mixture was filtered and the filtrate was evaporated by Rotary evaporator. After evaporation $2 \mathrm{gm}$ of hexane extract was obtained and was stored in air tight container. After fat removal from Ruellia tuberosa leaves, it was soaked in $3 \times 500 \mathrm{ml}$ of methanol for one week with occasional shaking. The mixture was filtered and the filtrate was evaporated by Rotary evaporator. After evaporation 3.4gm of sticky methanolic extract was obtained finally and designated as RTLE and kept in air tight container at $4^{\circ} \mathrm{C}$. Stock solution was prepared as $1 \mathrm{mg} / \mathrm{ml}$ in PBS from here desired concentrations $(25,50,100,200 \mu \mathrm{g} / \mathrm{ml})$ was used for in-vitro experiments.

\section{Cytotoxicity study by MTT assay}

Huh-7, SW480, HEK293T cells $\left(1 \times 10^{5}\right)$ were seeded in 96well sterile plates and were treated with different concentrations $(25,50,100,200 \mu \mathrm{g} / \mathrm{ml})$ of RTLE for 24,48 and $72 \mathrm{hrs}^{7}$ The treated cells were grown in humidified atmosphere containing $5 \% \mathrm{CO}_{2}$ in an incubator at $37^{\circ} \mathrm{C}$ and the untreated cells were considered as control. After 24, 48 and $72 \mathrm{hrs}$ incubation $20 \mu \mathrm{l}$ of MTT $(4-5 \mathrm{mg} / \mathrm{ml}$ in PBS as a stock solution) was added to each well and incubated again for 3 to $4 \mathrm{hrs}$ at $37^{\circ} \mathrm{C}$. MTT assay is a colorimetric assay for assessing the metabolic activity of the cells or cell viability of $\mathrm{NAD}(\mathrm{P}) \mathrm{H}$ dependent cellular oxido-reductase enzymes, and represents number of viable cells present. These enzymes are capable of reducing the tetrazolium dye MTT, which is yellow in colour, to insoluble purple colored formazan. The intensity of the colour was measured at $570 \mathrm{~nm}$ by micro-plate manager (Reader type: Model 680 XR Bio-Rad Laboratories Inc.).The IC $_{50}$ values were determined for the cells.

\section{Detection of cell morphological by Fluorescence Microscope}

Huh-7 cells $\left(1 \times 10^{6}\right)$ was treated with IC $_{\mathbf{5 0}}$ of RTLE for $24 \mathrm{~h}$ were observed using a fluorescence microscope for morphological changes. The untreated control cells and the RTLE treated cells were harvested separately, washed with PBS and then stained with acridine orange (100 $\mu \mathrm{g} / \mathrm{ml})$ and ethidium bromide $(100 \mu \mathrm{g} / \mathrm{ml})(1: 1)$. The cells were then immediately mounted on slides and observed under a fluorescence microscope in (Olympus, Fluoview FV10i) at 60x. for the morphological determination of the cells undergoing apoptosis.

\section{Detection of cell morphology by Confocal Microscope}

Huh-7 cells $\left(1 \times 10^{6}\right)$ was treated with $\mathrm{IC}_{50}$ of RTLE for $24 \mathrm{~h}$. After $24 \mathrm{hrs}$ the untreated control cells and RTLE treated cells were harvested and washed with ice cold PBS. The cells were then stained with $10 \mu \mathrm{g} / \mathrm{ml}$ of propidium iodide separately for $5 \mathrm{~min}$. After mounting on slides the cells were observed to see the differences in nuclear morphology between the untreated and the RTLE treated cells under confocal laser scanning microscope (Olympus, Fluoview FV10i) at 60x. Images for propidium iodide were acquired from argon/krypton laser and UV laser line using $590 \mathrm{~nm}$ long pass filter for propidium iodide and $450 \mathrm{~nm}$ band pass filter for UV images.

\section{Detection of DNA Fragmentation by Agarose Gel Electrophoresis}

Huh-7, SW480 cells $\left(1 \times 10^{6}\right)$ were treated with IC 50 dose but Hek293T cells treated with $100 \mu \mathrm{g} / \mathrm{ml}$ dose of RTLE for $24 \mathrm{~h}$ The cells were re-suspended in $500 \mu$ of lysis buffer (50 $\mathrm{mM}$ Tris- $\mathrm{HCl}$, pH 8.0, 10 mM EDTA, 0.5\% SDS), $100 \mu \mathrm{g} / \mathrm{ml}$ of proteinase $\mathrm{K}$ was added and incubation was done at 55 ${ }^{\circ} \mathrm{C}$ for $1 \mathrm{~h}$ and $37^{\circ} \mathrm{C}$ overnight respectively. ${ }^{8}$ DNA extraction was done by following the general phenol-chloroform extraction procedure and kept at $-20{ }^{\circ} \mathrm{C}$ overnight. After centrifugation, DNA precipitates were washed with $70 \%$ chilled ethanol, dried and evaporated at room temperature and dissolved in TAE buffer $\left(\mathrm{pH} \mathrm{8.0)}\right.$ at $4{ }^{\circ} \mathrm{C}$ overnight. To detect the DNA fragments, the isolated DNA samples were electrophoresed overnight at $20 \mathrm{~V}$ in $1 \%$ agarose gel and stained with ethidium bromide. DNA fragmentation was observed in UV transilluminator. (GENEI, Bangalore Genei Pvt. Ltd.)

\section{Detection of mitochondrial membrane potential $(\Delta \psi \mathrm{m})$ assay}

Huh-7, SW480, Hek293T $\left(1 \times 10^{6}\right)$ cells were treated with RTLE with desired dose and untreated as control for 24 hours to assay the mitochondrial membrane potential activity of cell in a flow cytometry. Cell were washed with PBS, pelleted down and eventually stained with JC-1 stain. The sample were incubated at $37^{\circ} \mathrm{C}$ for $15 \mathrm{~min}$. Shift in the mitochondrial membrane potential was determined by FACS (Becton Dickinson FACS Fortessa 4 leaser cytometer), Florence detector equipped with $520 \mathrm{~nm}$ argon laser light 
source and $623 \mathrm{~nm}$ band pass filter (liner scale) with the help of BD FACS Diva software (Becton Dickinson).

\section{Detection of Apoptosis by Flow Cytometric analysis}

In order to investigate the type of cell death induced by RTLE, flow cytometric analysis was done by performing dot plot assay. Huh-7, SW480, Hek293T $\left(1 \times 10^{6}\right)$ were treated with desired dose of RTLE for $24 \mathrm{~h} .{ }^{6}$ The cells were pelleted down, centrifuged at $2000 \mathrm{rpm}$ for $8 \mathrm{~min}$ at $4{ }^{\circ} \mathrm{C}$ and washed with Annexin V FITC binding buffer (10 mM HEPES, $140 \mathrm{mM} \mathrm{NaCl}$ and $2.5 \mathrm{mM} \mathrm{CaCl} 22 \mathrm{H} 2 \mathrm{O} ; \mathrm{pH} \mathrm{7.4).} \mathrm{Again} \mathrm{after}$ centrifuging at $2000 \mathrm{rpm}$ at $4{ }^{\circ} \mathrm{C}$, the cell pellets were dissolved in Annexin $\mathrm{V}$ FITC binding buffer containing annexin V FITC and propidium iodide. After $15 \mathrm{~min}$ incubation in dark at room temperature flow cytometric analysis was done. All data were acquired with a BectonDickinson FACS Caliber single laser cytometer. Flowcytometric reading was taken using $488 \mathrm{~nm}$ excitation and band pass filters of 530/30 $\mathrm{nm}$ (for FITC detection) and $585 / 42 \mathrm{~nm}$ (for PI detection). Live statistics were used to align the $X$ and $Y$ mean values of the Annexin-V FITC or PI stained quadrant populations by compensation. Data analysis was performed with Cell Quest (Macintosh platform) program.

\section{Detection of Cell Cycle Arrest by Flow Cytometric Analysis}

In order to study the stage of cell cycle arrest in flow cytometry Huh-7, SW480 \& Hek293T cells $\left(1 \times 10^{6}\right)$ were treated with desired of RTLE for $18 \mathrm{~h}$. Cells were washed with PBS, fixed with cold methanol by adding methanol drop-wise and kept at $-20{ }^{\circ} \mathrm{C}$ for $3 \mathrm{~min}$. They were then resuspended in cold PBS and kept at $4{ }^{\circ} \mathrm{C}$ for $90 \mathrm{~min}$. Cells were pelleted down, dissolved in cold PBS, treated with RNase $A$ for $30 \mathrm{~min}$ at $37{ }^{\circ} \mathrm{C}$ and stained with propidium iodide $(20 \mu \mathrm{l}$ from $50 \mu \mathrm{g} / \mathrm{ml})$ and kept in dark for $15 \mathrm{~min}$. Cell cycle phase distribution of nuclear DNA was determined on BD FACS Diva software (Becton Dickinson FACS).$^{9}$

\section{Statistical Analysis}

Percentage of cell growth inhibition was calculated by the following formula: \% Cell Inhibition= $10 \times$ (O.D of Control O.D. Of treated /O. D. of Control), O. D= Optical Density.

Percentage of cell viability was calculated as follows: Viable Cells $(\%)=($ Total number viable cells per $\mathrm{ml} /$ Total number of cells per $1 \mathrm{ml}) \times 100$.

\section{RESULTS}

\section{Cytotoxicity study by MTT assay}

In the MTT assay, Huh-7, SW480, cells there was significant reduction in the O.D values after treating all the, the with RTLE in a time and concentration dependent manner compared to that of control cells whereas in HEK293T cells insignificant reduction in the O.D values were observed. These observations provided proof for cytotoxic nature of RTLE towards only on all the carcinoma cell lines. The $I_{50}$ value of RTLE was $44.97 \mu \mathrm{g}$ for Huh-7 cells, $41.6 \mu \mathrm{g}$ for SW480 respectively.
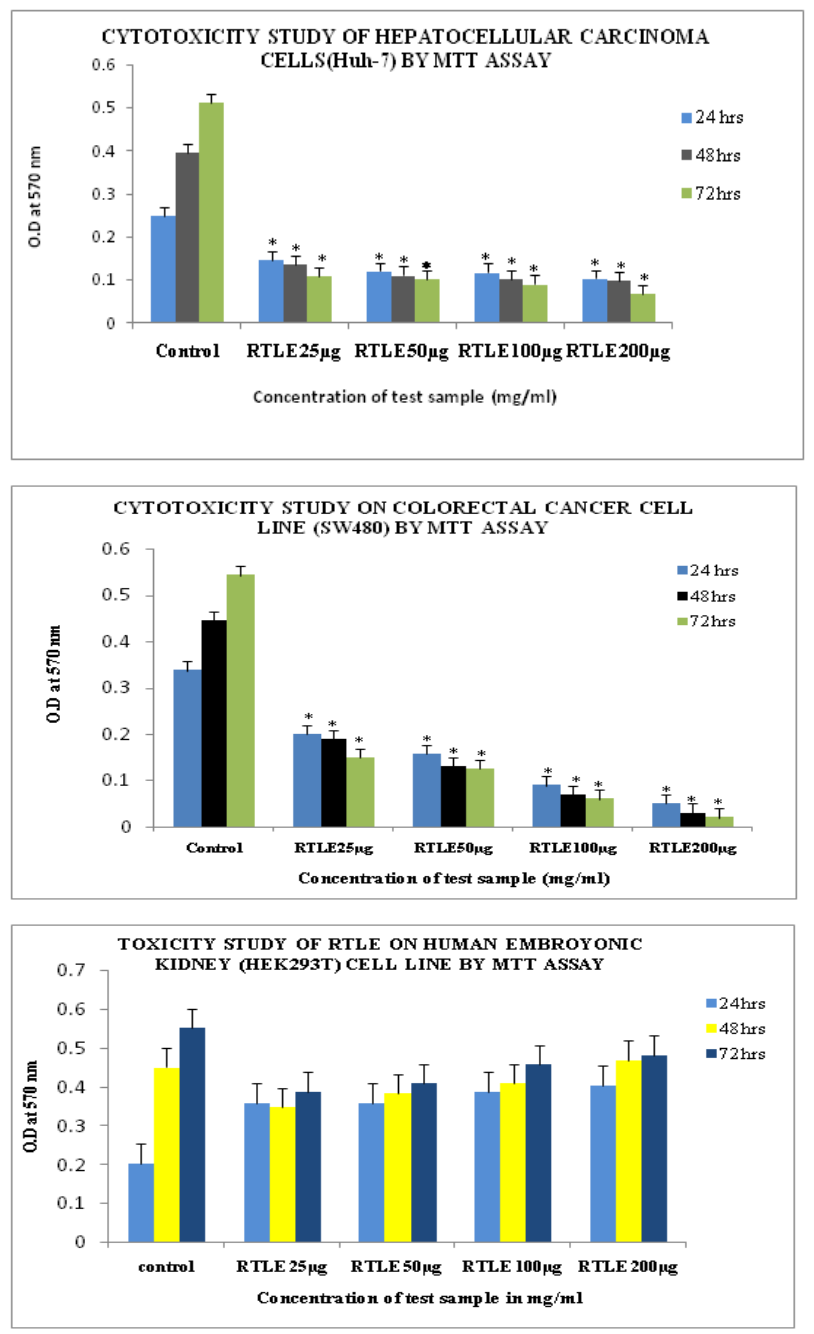

Figure 1: Histogram Showing the O.D. values of Huh-7, SW480, Hek293T cells treated with RTLE.RTLE treated all the carcinoma cells showed significant reduction in O.D. value in a time and concentration dependent manner whereas in normal cells showed insignificant reduction in the O.D. Values up to $72 \mathrm{hrs}$. Data are mean \pm S.E.M.

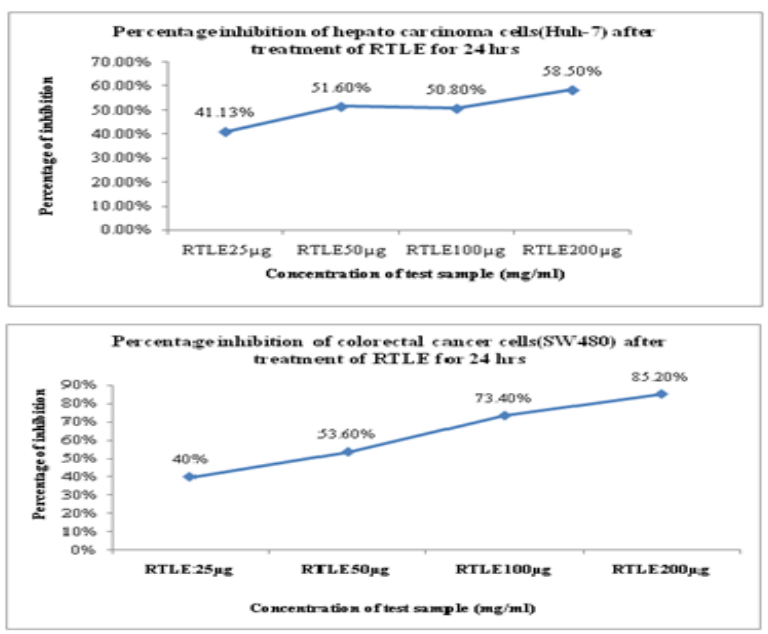

Figure 2: Line graph shows the percentage inhibition of viable cells in Huh-7, SW480 cells treated with RTLE for 
24hrs. RTLE treated cells significantly increases the \% inhibition in a time and concentration dependent manner. The IC 50 value of RTLE were calculated for Huh-7 44.97 $\mu \mathrm{g}$, SW480 41.6 $\mathrm{gg}$ for $24 \mathrm{hrs}$ respectively.

\section{Detection of cell morphology by Fluorescence \& Confocal Microscope}

Observations revealed that RTLE treated and control Huh7 cells was stained with both acridine orange and ethidium bromide confirm the presence of apoptotic cells early and late as compared to the untreated control cells. In this study nuclear changes were observed including chromatin condensation and apoptotic body formation that are the indication of apoptotic processes. Apoptosis further confirmed by confocal images of RTLE induced apoptotic changes in Huh-7cells after $24 \mathrm{~h}$ of treatment showing chromatin disintegration and formation of apoptotic bodies whereas the untreated control cells were with intact nucleus.

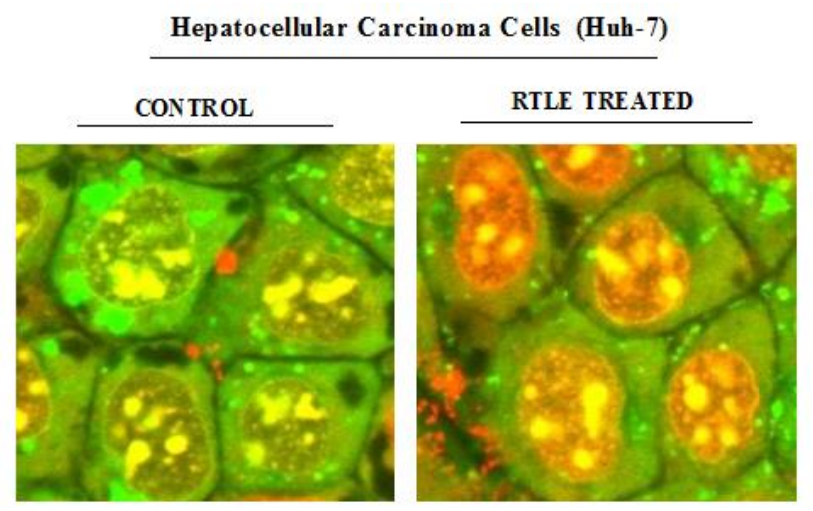

Figure 3: Fluorescence and confocal microscopic images of both the untreated control and RTLE treated hepatocellular carcinoma cells. Control cells give a bright green fluorescence whereas the treated cells show an orange red colour, demarking the occurrence of Apoptosis in hepatocellular carcinoma, Huh-7 cells.

\section{Hepatocellular carcinoma cells(Huh-7)}

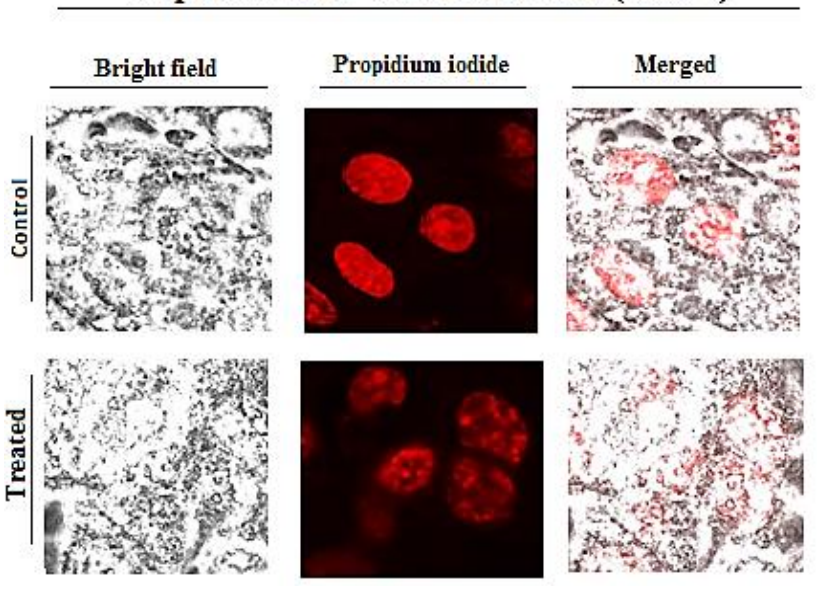

Figure 4: Confocal microscopic image of Huh-7 cell line after 24 hours of treatment with RTLE. Treated cells showed nuclear fragmentation which is a sign of apoptosis whereas control cells showed intact nucleus which has been indicated by arrow.

\section{Detection of DNA Fragmentation by Agarose Gel Electrophoresis}

The gel pattern of the DNA samples isolated from untreated control Huh-7, SW480 cells showed intact DNA bands, whereas the gel pattern of the DNA samples isolated from RTLE treated Huh-7 and SW480 cells showed degraded DNA bands in the form of ladders. So, the observations confirmed that the treatment with RTLE in both the cells caused apoptosis.
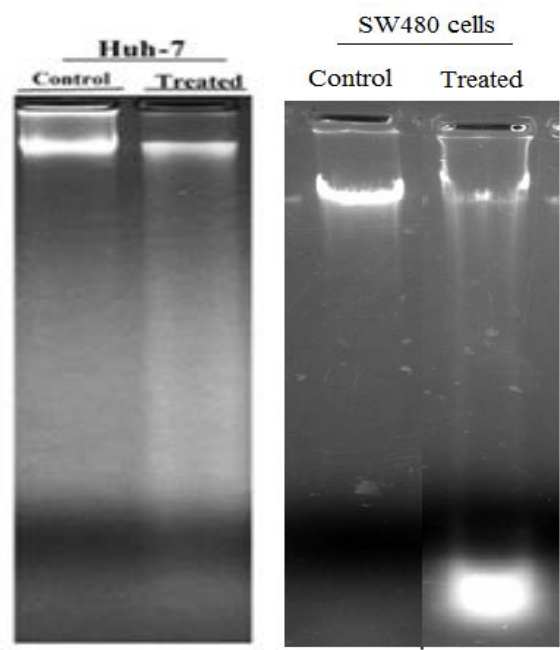

Figure 5: DNA fragmentation by agarose gel electrophoresis in Huh-7 and SW480cells. Lane 1 represent control cells which shows intact DNA whereas Lane 2 represent RTLE desired dose treated cells in which DNA fragments are clearly visible in carcinoma cells.

\section{Detection of mitochondrial membrane potential $(\Delta \psi \mathrm{m})$ assay}

Mitochondrial dysfunction is an essential target for induction of apoptosis. The hepatocellular carcinoma (Huh-7), colorectal cancer (SW480) and normal(Hek293T) cell lines when treated with desired dose of RTLE, there was a loss of Mitochondrial Membrane Potential $(\Delta \psi \mathrm{m})$ of cancer line and insignificant loss in normal cell line. The JC1 stain cannot accumulate in the mitochondria of the apoptotic cells, as the mitochondrial membrane potential collapses, hence showing green fluorescence (P4) denotes apoptotic cells and red fluorescence (P3) denoting healthy cells where JC-1 stain accumulates. Depolarization in mitochondrial membrane potential was observed by staining untreated and treated cell by JC-1 dye. The depolarization led to a transmembrane shift from red to green fluorescence leading to release of cytochrome c. A significant transmembrane shift of $9.6 \%$ to $41.7 \%, 12.4 \%$ to $58.5 \%$ were observed when Huh-7, SW480 cells were treated with the $I_{50}$ value of RTLE for 24 hours respectively. But an insignificant transmembrane shift of $14.6 \%$ to $9 \%$ were observed when HEK293T was treated with the desired dose of RTLE for 24 hours. 

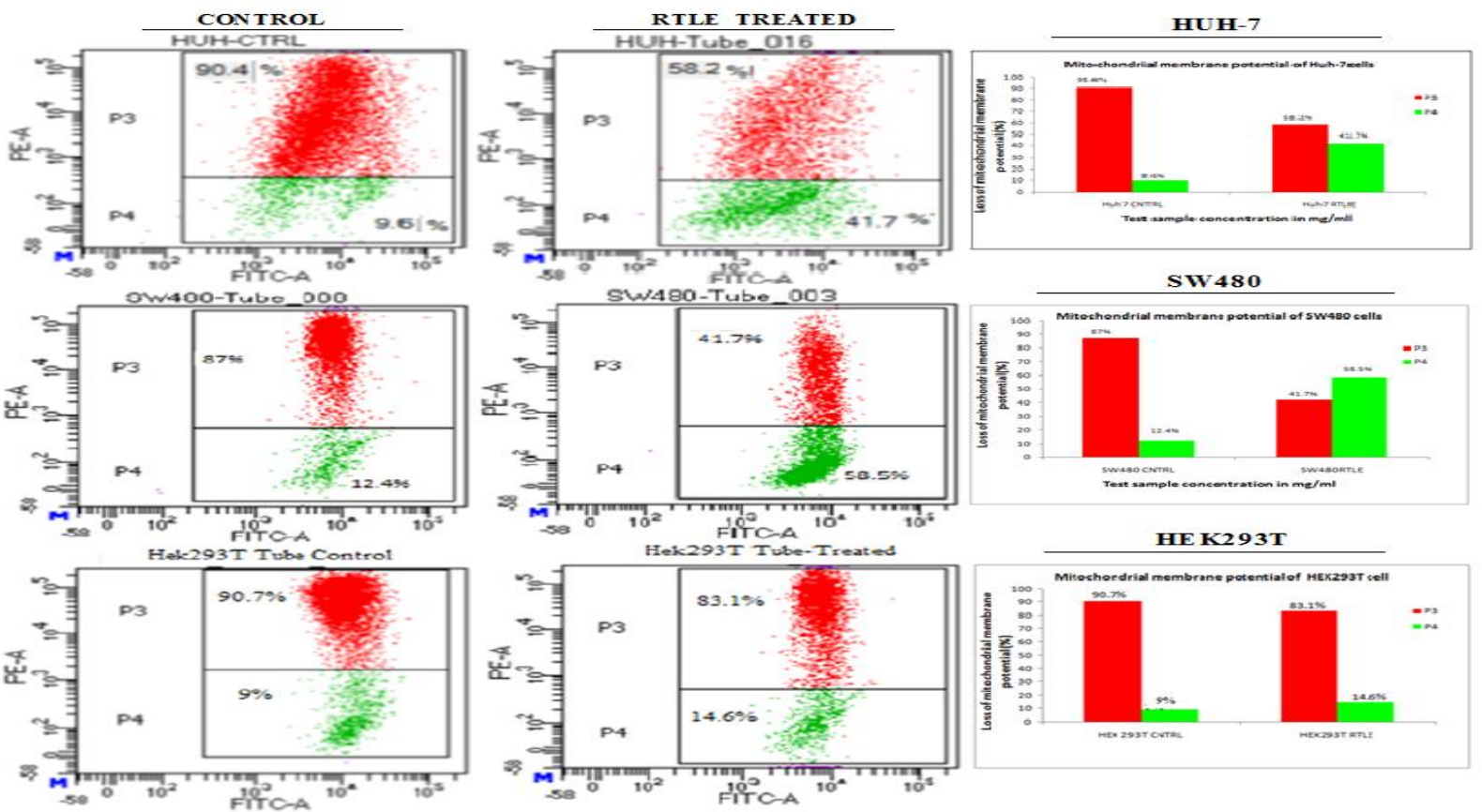

Figure 6: Flow cytometric analysis of mitochondrial membrane potential $(\Delta \psi \mathrm{m})$ on Huh-7, SW480 and HEK293T cell lines in both control and RTLE treated cells respectively after $24 \mathrm{hrs}$ of treatment. Transmembrane shift was significantly increased in Huh-7, SW480 cells whereas in the normal HEK 293T cells insignificant increase observed when treated with desired dose of RTLE. Histogram showing the fold's decrease in mitochondrial membrane potential $(\Delta \psi \mathrm{m})$ in Huh-7 and SW480 cells and increase in mitochondrial membrane potential $(\Delta \psi \mathrm{m})$ in HEK 293T cells when treated with RTLE.

\section{Detection of apoptosis by flow cytometry}

In the flow cytometric analysis, double labeling technique, using Annexin V-FITC and propidium iodide, was utilized. Lower left (LL) quadrant (Annexin V-/PI-) is regarded as the population of live cells, lower right quadrant (LR) (Annexin $\mathrm{V}+$ (PI-) is considered as the cell population at early apoptotic stage, upper right (UR)quadrant (annexin $\mathrm{V}+\mathrm{PI}+$ ) represents the cell population at late apoptotic stage. Flow cytometric data analysis revealed that after
$18 \mathrm{~h}$ of treatment with desired dose of RTLE for quantification of apoptosis was observed for Huh-7 1.2\% against $22.3 \%$, SW480 0\% against 25\%, cells were in upper right quadrant which implies apoptotic cells thereby, showing apoptotic inducing property of RTLE on colorectal and hepatoma cells. In normal cells HEK293T $80.5 \%$ against 80.9\% cells were in upper right quadrant does not implies apoptotic cells thereby, RTLE shows non-apoptotic inducing property towards both the normal cell lines.
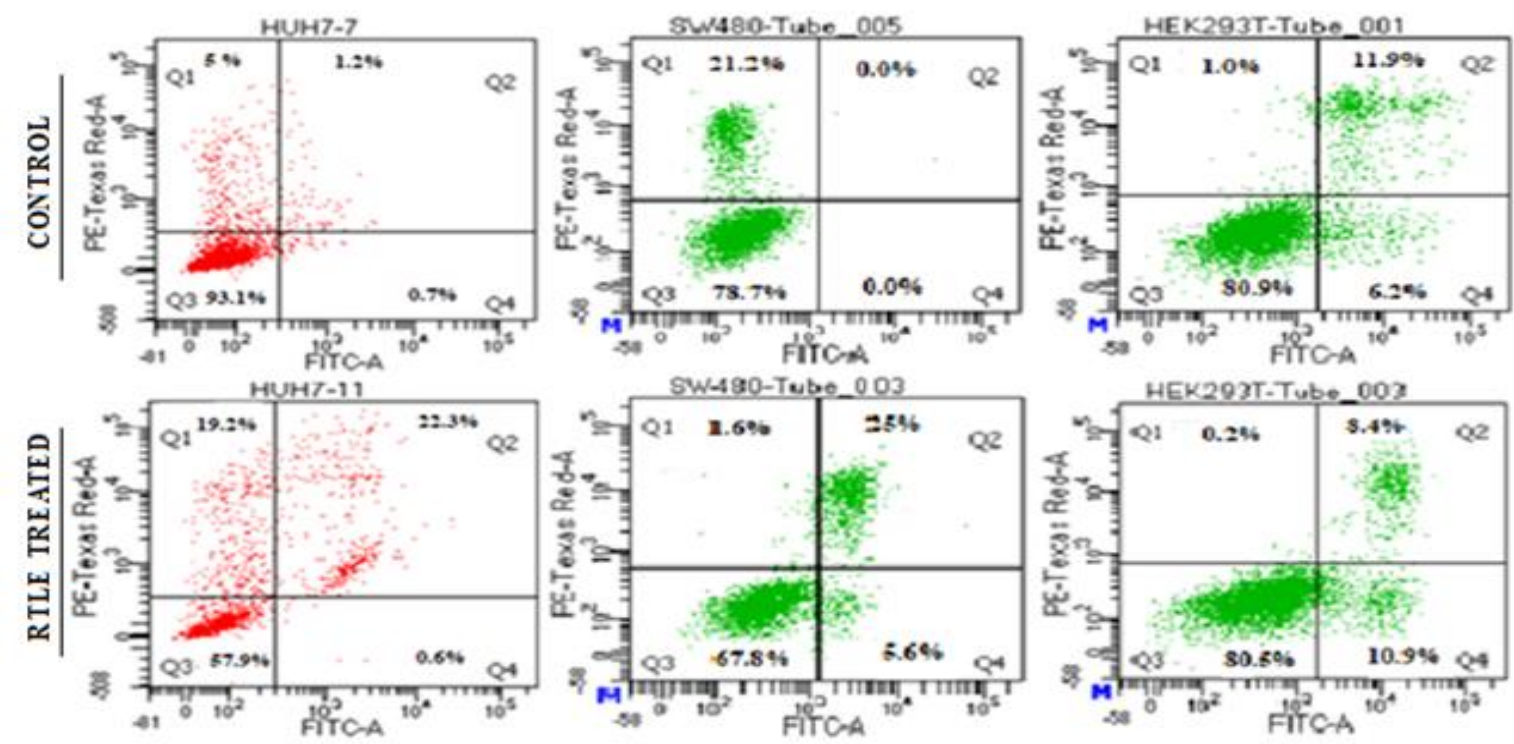

Figure 7: Flow cytometric analysis of untreated control and RTLE treated of Huh-7, Sw480 and HEK 293T cells respectively stained with Annexin V FITC and propidium iodide. Dual parameter dot plot of FITC fluorescence ( $x$-axis) vs PI-fluorescence (y-axis) shows logarithmic intensity. 


\section{Detection of Cell Cycle Arrest by Flow Cytometric Analysis}

Flow cytometry analysis showed that after $24 \mathrm{hrs}$ treatment of Huh-7, SW480 cell lines with RTLE at desired dose, sub-G1 peak was markedly changed, but in case of Hek293T cells insignificant change at sub-G1 peak was
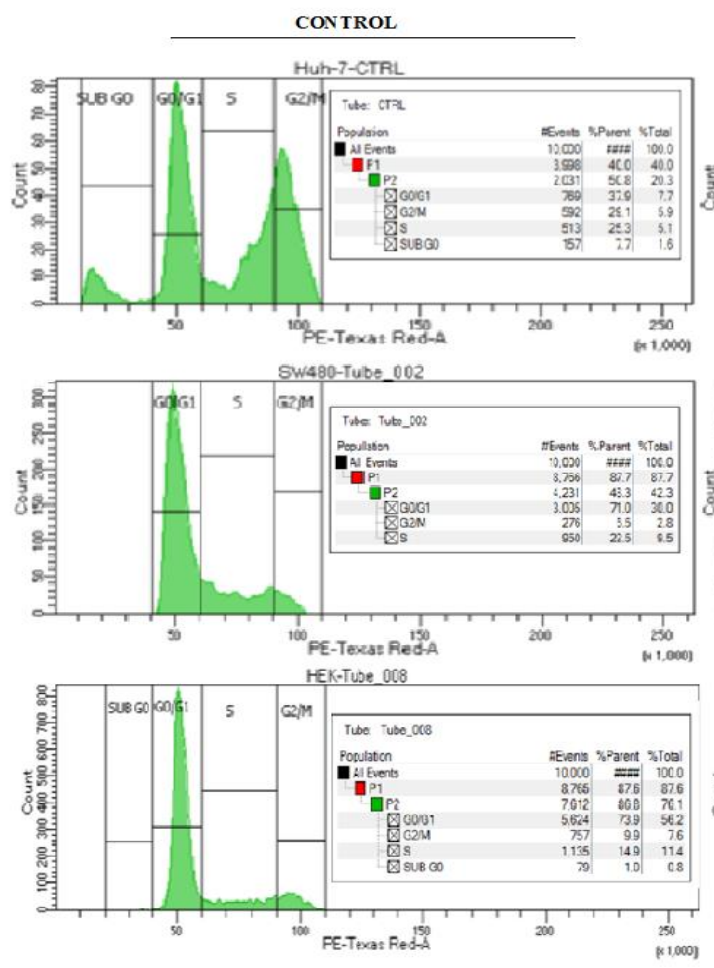

observed. The DNA content increase in RTLE treated cell $56 \%$ against $37.9 \%$ in Huh-7, 32.2\% against 30\% in SW480, $70.9 \%$ against $71 \%$ in HEK293T cells. These observations revealed that RTLE significantly inhibited the growth of Huh-7, SW480, cells by arresting the cell populations in the sub-G0/G1 phase of the cell cycle.
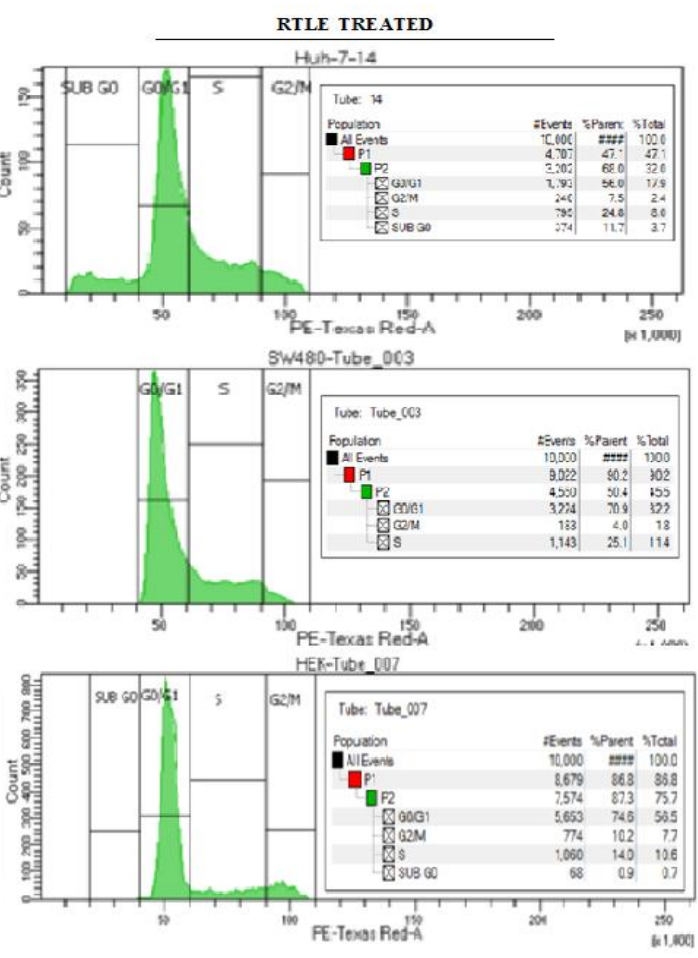

Figure 8: Flow cytometric analysis of cell cycle phase distribution in control and treated Huh-7, SW480, Hek293T cells respectively after $18 \mathrm{hrs}$ treatment at desired dose of RTLE.

\section{DISCUSSION}

Hepatocellular carcinoma (HCC), or hepatoma accounts for more than $90 \%$ of all cases of primary liver cancer and colorectal cancer is one of the most common cancer in people over 50 years both in the developed and developing countries. Primary liver cancer includes hepatocellular carcinoma (HCC) (comprising $75 \%-85 \%$ of cases) and intrahepatic cholangiocarcinoma (comprising 10\%-15\% of cases) as well as other rare types. The main risk factors for $\mathrm{HCC}$ are chronic infection with hepatitis B virus (HBV) or hepatitis $\mathrm{C}$ virus (HCV), aflatoxin-contaminated foodstuffs, heavy alcohol intake, obesity, smoking, and type 2 diabetes. ${ }^{10}$ The rising obesity prevalence is considered a contributory factor to the observed increasing incidence of HCC in low-risk HCC areas. ${ }^{11}$ Primary prevention of the majority of liver cancer cases has been feasible through a vaccine against HBV since 1982, and future benefits of this vaccine will accrue as younger generations vaccinated in childhood reach the ages where liver cancer becomes common. The WHO recommends its inclusion in routine infant immunization programs and, by the end of 2016, 186 countries had introduced the HBV vaccine into their national immunization schedules with many countries achieving greater than $80 \%$ coverage for the full recommended dose. ${ }^{12}$ The vaccine has dramatically reduced the prevalence of $\mathrm{HBV}$ infection and the incidence of HCC at younger ages in high-risk countries in East Asia, where mass vaccination was first introduced. ${ }^{13}$ However, currently, there is no vaccine available to prevent HCV infection. Although there have been substantive declines in HCV transmission in highly resourced countries, the continued use of contaminated needles and unsafe transfusions contribute to the spread of infection in several low-income countries. ${ }^{14}$

Colorectal cancer Over 1.8 million new colorectal cancer cases and 881,000 deaths are estimated to occur in 2018 , accounting for about 1 in 10 cancer cases and deaths. Overall, colorectal cancer ranks third in terms of incidence but second in terms of mortality. Colorectal cancer incidence rates are about 3-fold higher in transitioned versus transitioning countries; however, with average case fatality higher in lower HDI settings, there is less variation in the mortality rates. Colorectal cancer incidence rates vary widely, with 8-fold and 6-fold variations in colon and rectal cancer, respectively, by world region; the disease can be considered a marker of socioeconomic development and, in countries undergoing major development transition, incidence rates tend to rise uniformly with increasing HDI. ${ }^{15,16}$ Assessing incidence and mortality trends the types of cells that most commonly give rise to colorectal cancers is the adenocarcinoma which is cancer of the cells that line the inside tissue of the colon 
and rectum. ${ }^{17}$ Treatment efficiency of colorectal and liver cancer is low, therefore colorectal and liver cancer prevention and control is extremely important. Recent developments in the treatment of HBV and HCV suggest that large numbers of liver cancer cases could be avoided, although the costs are prohibitive at present. ${ }^{10}$ Ruellia tuberosa L. (Acanthaceae), is a tropical plant which is widely distributed in Southeast Asia. In folk medicine, it has been used as diuretic, antidiabetic, antipyretic, analgesic, antihypertensive and antidotal agent. It has different names such as Minnie Root, Fever Root, Snapdragon Root and Sheep Potato. In Sabah, Malaysia, the plant is called by the local as "Cracker Plant" as the seeds burst when comes in contact with water. The plants can be easily found in the shady and moisture place such as side drain. Recently, it has been incorporated as a component in an herbal drink in Taiwan. However, very few chemical constituents and pharmacological activities have been reported on this species. The whole plant has been shown to possess antimicrobial activity and the stem has also been shown to possess antioxidant activity. ${ }^{18,19}$

The anticancer activity of Ruellia tuberosa leaf extract (RTLE) using hepatocellular carcinoma (Huh-7), colorectal cancer (SW480) and its effect on normal human kidney (HEK293T) was studied. The cytotoxic activities of RTLE were supported by the observations in MTT assays. RTLE showed the anti-proliferative activities of metabolically active Huh-7 \& SW480 cells in a concentration and time dependent manner. We also studied the toxic effect of RTLE on HEK293T cells. In MTT assay of RTLE treated HEK293T cells insignificant inhibition took place in a nonconcentration and time dependent manner. Anti-cancer activity of RTLE was investigated by different morphological studies like fluorescence microscopic, confocal microscopic in hepatocellular carcinoma cells. The process of apoptosis is characterized by several morphological changes such as cell shrinkage, membrane blebbing, chromatin condensation, nuclear fragmentation and formation of apoptotic bodies. Fluorescence microscopic images clearly showed nuclear disintegration of RTLE treated hepatocellular carcinoma cells compared with that of the untreated control cells when stained with acridine orange and ethidium bromide. The untreated control cells showed bright green fluorescence. On the contrary RTLE treated cells showed more intense orangered fluorescence and reduced green fluorescence. The observations indicated that the treatment of Huh-7 cells with RTLE shows apoptosis. Apoptosis activity of RTLE was further evidenced from the confocal microscopic images of the treated hepatocellular carcinoma cells when compared with that of the untreated control cells. After RTLE treatment, Huh-7 cells showed several signs of apoptosis like chromatin condensation, nuclear fragmentation and formation of apoptotic bodies whereas the untreated control cells were with intact nuclei.

Further evidence in support of the anti-cancer activity of RTLE was obtained from the gel patterns of agarose gel electrophoresis. RTLE treated both the cells showed degraded DNA bands in the form of ladders, a typical indication of apoptosis, whereas the untreated control cells showed intact DNA bands when observed in UV transilluminator. The mitochondrial membrane potential assay by JC-1dye showed increase in mitochondrial membrane potential in both Huh-7 \& SW480 cells but did not increase in case of Hek293T cells. Experiments also showed increased number of cells in the late apoptotic stage after treatment of Huh-7 cells\& SW480cells with RTLE which implies the fact that apoptosis was triggered by the treatment with RTLE in Huh-7 cells\& SW480cells but not in case of Hek293T cells. Cell cycle analysis revealed that treatment of Huh-7\& SW480cells with RTLE arrested the Huh-7 \& SW480cells cell populations in the sub Go/G1 phase of cell cycle. However, RTLE did not change populations of Hek293T cells in the sub $G_{0} / G 1$ phase of cell cycle.

\section{CONCLUSION}

It has been concluded that RTLE possess anti-proliferative and cytotoxic effect against hepatocellular carcinoma cell (Huh-7) and Colorectal cancer (SW480) cells but it shows insignificant inhibition and non- apoptotic activity against normal human embryonic kidney cells (HEK293T). Therefore, we can conclude that RTLE specifically shows activity in cancer cells. The plant Ruellia tuberosa possesses lots of medicinal value. It can be considered as a potent anti-cancer agent for treatment of hepatocellular carcinoma and Colorectal cancer with less side effects. Further mechanistic study should be done and identify the active compounds which are responsible for anticancer activity of Ruellia tuberosa on both the adenocarcinoma.

Acknowledgement: The authors of this paper are very much thankful to Council of Scientific and Industrial Research, Indian Institute of Chemical Biology (CSIR-IICB), Kolkata for providing the platform to perform the research work.

\section{REFERENCES}

1. Doll $R$ and Peto R, The causes of cancer, Journal of the National Cancer Institute, 1981; 66: 1191-308.

2. Kumar V, Abbas A, Aster J, Robbins C, Pathologic Basis of Diseases, Elsevier, 2014; 30(4): 272-278.

3. Salem R, Lewandowski R J, Chemo embolization and radio embolization for hepatocellular carcinoma. Clin. Gastroenterology Hepatol, 2013; 11: 604.

4. Daya L C, Patel MB, Mishra SH, Review on Ruellia tuberosa, PHCOG J, 2010; 2(12): 506-512.

5. Nagarjuna V, Nagarathna PKM, Divya M, Evaluation of anticancer activity of Ruellia tuberosa on EAC induced mammary tumour, International Journal of Pharmacology and Toxicology, 2013; 1(2): 36-42.

6. Dey S, Roy S, Deb N, Sen K, Besra SE, Anti-carcinogenic activity of Ruellia tuberosa $L$. (Acanthaceae) leaf extract on hepatoma cell line \& increased superoxide dismutase activity on macrophage cell lysate, International Journal of Pharmacy and Pharmaceutical Sciences, 2013; 5(3): 885861. 
7. Cao $\mathrm{Z}$ and Li Y. Chemical induction of cellular antioxidants affords marked protection against oxidative injury in vascular smooth muscle cells, Biochem Biophysics Res Commun, 2002; 292: 50-57.

8. Walker PR, Koki leva L, LeBlanc J, Sikorska M, Detection of the initial stages of DNA fragmentation in apoptosis. Bio Techniques. 1993; 15: 1032-40.

9. Roy S, Besra SE, De T, Banerjee B, Mukherjee J, Vedasiromoni JR. Induction of Apoptosis in Human Leukemic Cell Lines U937, K562 and HL-60 by Litchi chinensis Leaf Extract Via Activation of Mitochondria Mediated Caspase Cascades. The Open Leukemia Journal. 2008; 1:1-14.

10. London WT, Petrick JL, Mc Glynn KA. Liver cancer. In: Thun MJ, Linet MS, Cerhan JR, Haiman CA, Schottenfeld D, eds. Cancer Epidemiology and Prevention. 4th Ed. New York: Oxford University Press; 2018;635-660.

11. Marengo A, Rosso C, Bugianesi E. Liver cancer: connections with obesity, fatty liver, and cirrhosis. Annu Rev Med. 2016; 67:103-117.

12. World Health Organization. Global Health Observatory (GHO) data: Hepatitis B 3rd Dose (HepB3) Immunization Coverage. Geneva: World Health Organization; 2017.
13. Chang $\mathrm{MH}$, Chen $\mathrm{CJ}$, Lai MS, et al. Universal hepatitis B vaccination in Taiwan and the incidence of hepatocellular carcinoma in children. Taiwan Childhood Hepatoma Study Group. N Engl J Med 1997; 336:1855-1859.

14. Thursz $M$, Fontanet $\mathrm{A}, \mathrm{HCV}$ transmission in industrialized countries and resource-constrained areas, Nat Rev Gastroenterol Hepatol. 2014; 11:28-35.

15. Bray F. Transitions in human development and the global cancer burden. In: Stewart BW, Wild CP, eds. World Cancer Report 2014. Lyon: IARC Press; 2014:42-55.

16. Fidler MM, Soerjomataram I, Bray F. A global view on cancer incidence and national levels of the Human Development Index. Int J Cancer. 2016; 139:2436-2446.

17. Arnold $M$, Sierra MS, Laversanne $M$, Soerjomataram I, Jemal A, Bray F. Global patterns and trends in colorectal cancer incidence and mortality, Gut, 2017; 66: 683-691

18. Arirudran B, Saraswathy A, Krishnamurthy V. Antimicrobial Activity of Ruellia tuberosa L. (Whole Plant), Pharmacognosy Journal, 2011; 3(23):91-95.

19. Chen FA. Wu. Ab. Shieh. P. Kvo. DH. Hsieh CY. Evaluation of the antioxidant activity of Ruellia tuberosa, Food chem, 2006; 94:14-18.

Source of Support: The author(s) received no financial support for the research, authorship, and/or publication of this article.

Conflict of Interest: The author(s) declared no potential conflicts of interest with respect to the research, authorship, and/or publication of this article.

For any question relates to this article, please reach us at: globalresearchonline@rediffmail.com New manuscripts for publication can be submitted at: submit@globalresearchonline.net and submit_ijpsrr@rediffmail.com 